\title{
How Do Pandemics Affect Government Expenditures?
}

\author{
Qiang Fu ${ }^{1}$ (D) ${ }^{\mathrm{a}}$, Chun-Ping Chang ${ }^{2}$ \\ ${ }^{1}$ Changsha University of Science and Technology \& Hunan Open University, Hunan China, ${ }^{2}$ Shih Chien University, Kaohsiung, Taiwan \\ Keywords: covid-19, government expenditure, pandemic \\ 10.46557/001c.21147
}

\section{Asian Economics Letters}

Vol. 2, Issue 1, 2021

Based on a sample of panel data for 14 countries spanning the period 2000-2018, this paper investigates the effect of pandemics on government expenditure and public health expenditure. The empirical results show that pandemics lead to an increase in government health expenditure, but the positive effect on total government expenditure may not be statistically significant.

\section{Introduction}

The outbreak of COVID-19 in late 2019 led to country lockdowns, which became effective in reducing the number of new cases (Alfano \& Ercolano, 2020). On the other hand, though, as people stayed home to prevent the spread of the infection, economic activities stagnated in many countries. To control the spread of the pandemic and revive the economy, government expenditures can be used as a tool. This paper thus analyzes the effect of infectious diseases on government expenditure. Our main hypothesis is that the pandemic/epidemic (hereafter pandemic) outbreaks will have a positive effect on government expenditure. Governments increase expenditure on public health in times of pandemics and further boost expenditures on economic recovery during the post-pandemic years. This hypothesis test is motivated by the endogenous growth model of public expenditure (Kum et al., 2019). Government expenditures are an integral part of economic growth, but the economic damage caused by pandemics strains government revenues. With COVID-19 still unfolding, it is informative to study how pandemics affect government spending.

According to Sha \& Sharma (2020) and Sharma \& Sha (2020), several studies have examined the impacts of COVID-19 on different aspects of the economy, such as global trade (Vidya \& Prabheesh, 2020), exchange rate (Iyke, 2020; Narayan, 2020c), labor force (Yu et al., 2020), energy market (Narayan, 2020b; Salisu \& Adediran, 2020), financial markets (Mishra et al., 2020; Narayan, 2020a) stock market (He et al., 2020; Phan \& Narayan, 2020; Salisu \& Sikiru, 2020), and environmental quality (Ming et al., 2020). Haldar \& Sethi (2020) also focused on government intervention and showed that government stringency is an important factor in reducing the incidence of COVID-19. Distinct from this literature, our paper focuses on the im- pacts and challenges faced by governments during pandemic outbreaks, with the aim of investigating how pandemics affect government expenditure.

Our paper adds to the literature by undertaking the following. First, we analyze the influence mechanism of pandemics on government expenditure based on the endogenous growth model of public expenditure. Second, we study the impact of pandemics on government expenditure and public health expenditure by using data of the three largescale pandemics (SARS, H1N1, and EVD) over the past 20 years. Third, we draw implications for the effects of COVID-19on government expenditure and offer policy recommendations for the post- pandemics phase of recovery.

\section{Influence mechanism}

Previous research has discussed the economic impacts of pandemics such as SARS and Ebola (Lee \& Mckibbin, 2004; Maliszewska, 2014). We argue that pandemics will influence the economy through the following aspects. First, pandemics directly disrupt labor force and human capital due to its high infectivity (cases) and deaths, and then transmit the adverse effects to the economy (Lee \& Mckibbin, 2004). Second, pandemics dampen consumer demand and increase prevention costs (Kum et al., 2019), putting a strain on individual wealth, business income and growth and government finances. Third, pandemics undoubtedly adversely influence foreign trade and foreign direct investment.

The endogenous growth model of public expenditure discusses the effect of government expenditure on economic growth. On one hand, government can promote economic growth by improving capital productivity through investment in research and development (R\&D) and infrastructure (Goel et al., 2008), on the other hand, government expenditure on human capital, positively affects economic

\footnotetext{
a Corresponding Author Email: fisywell@126.com

Qiang Fu acknowledges funding support from the second batch of 2019 national college students' innovation team cultivation project (054 | 2003002). We are also grateful for helpful comments and suggestions from the editor and an anonymous reviewer of this journal. We are solely responsible for any remaining errors and/or omissions.
} 
growth by increasing labor productivity and the resultant labor supply (Awaworyi et al., 2015; Guo et al., 2011; Narayan \& Smyth, 2005). However, government expenditures on R\&D, infrastructure, and education are probably compelled to transfer to the public health sector during the pandemic period to control the pandemic and provide social help. Birchenall (2007) states that the improvement of a population's health level has a positive effect on economic growth. In order to restore the economic situation damaged by COVID-19 and given the role of government expenditure on economic growth, we naturally want to analyze more deeply how pandemics influence government expenditure.

\section{Data and Result}

\section{A. Data and model}

We utilize data for the periods spanning the Severe Acute Respiratory Syndrome (SARS), H1N1 flu, and Ebola Virus Disease (EVD) to investigate the impacts of these pandemics on government expenditure in countries and regions that were most affected. Therefore, we use annual data from years 2000 to 2018 for a panel of 14 sample countries. The data come from the World Development Indicators and the World Health Organization.

Assuming that total general government expenditure is a function of pandemic outbreak, we present the equation:

$$
G E=f(P)
$$

Following Kum et al. (2019), we select other variables that affect government expenditure as control variables. These include population growth, life expectancy, gross domestic product (GDP) per capita, government revenue, and national income per capita. The results of the Hausman test show that the fixed effect model is more suitable for our data since the $p$-value is less than 0.1 . Therefore, we modify Equation (1) as:

$$
\begin{aligned}
G E_{i, t}= & \alpha_{0}+\alpha_{1} P_{i, t}+\alpha_{2} P G_{i, t}+\alpha_{3} L E_{i, t} \\
& +\alpha_{4} G D P_{i, t}+\alpha_{5} G R_{i, t}+\alpha_{6} N I_{i, t} \\
& +\mu_{t}+\nu_{i}+\varepsilon_{i, t}
\end{aligned}
$$

where $G E$ represents the dependent variable, government expenditure, $P$ stands for the main explanatory variable pandemic (which is set as a dummy variable that equals 1 if there exists cases of SARS, H1N1, or EVD in that year and otherwise 0$), P G$ represents population growth, $L E$ represents life expectancy, GDP represents GDP per capita, $G R$ represents government revenue, $N I$ represents national income per capita, $\mu_{t}$ and $\nu_{i}$ are the fixed effect variables for time and country/region, respectively, and $\varepsilon_{i, t}$ is the error term. Due to the large numerical differences of some independent variables, we take the logarithm of variables.

The heterogeneity of some important attributes may exist in our sample of countries when studying multiple groups or samples. For the robustness test, therefore, we divide the full sample of countries into two sub-samples, namely, developing countries and developed countries.

\section{B. Results}

Table 2 shows the full sample results estimated by the panel fixed effect model. Model 1 reports the effects of the pandemic on government expenditure, while model 2 pre-
Table 1: Sample selection

\begin{tabular}{cc}
\hline Pandemic & $\begin{array}{c}\text { Sample countries/ } \\
\text { regions }\end{array}$ \\
\hline $\begin{array}{c}\text { Severe Acute Respiratory } \\
\text { Syndrome (SARS) }\end{array}$ & China \\
& Canada \\
& Hong Kong, China, \\
H1N1 flu & Argentina \\
& China \\
India \\
Mexico \\
United States \\
\hline Dbola Virus Disease (EVD) & Democratic Republic \\
of Congo \\
Guinea \\
Liberia \\
Mali \\
Nigeria Leone \\
\hline
\end{tabular}

Note: This table lists the sample countries that were most affected by these pandemics/ epidemics.

Table 2: Estimation results

\begin{tabular}{c|cc}
\hline Variable & $\begin{array}{c}\text { Model 1 } \\
\text { (dependent } \\
\text { variable: } \\
\text { government } \\
\text { expenditure) }\end{array}$ & $\begin{array}{c}\text { Model 2 } \\
\text { (dependent } \\
\text { variable: } \\
\text { government health } \\
\text { expenditure) }\end{array}$ \\
\hline Pandemic & 1.207 & $0.347^{* * *}$ \\
Population & $(1.177)$ & $(0.084)$ \\
growth & -0.019 & $0.165^{*}$ \\
Life & $(0.062)$ & $(0.082)$ \\
expectancy & 2.918 & 2.228 \\
GDPper & $(2.914)$ & $(2.435)$ \\
capita & -0.114 & 0.367 \\
Government & $(0.295)$ & $(0.356)$ \\
revenue & 0.026 & 0.027 \\
National & $(0.022)$ & $(0.026)$ \\
income per & $0.900^{* * *}$ & 0.374 \\
capita & $(0.118)$ & $(0.286)$ \\
Constant & 2.047 & -12.285 \\
Observation & $(10.622)$ & $(9.297)$ \\
R & 171 & 171 \\
F-value & 0.069 & 0.067 \\
\hline & 613.73 & 18.15 \\
\hline & & \\
\hline & & \\
\hline
\end{tabular}

Note: This table reports the full sample results of the panel fixed effect model. The val ues in parentheses denote the standard errors. Finally, ${ }^{*}, * *$, and ${ }^{* * * *}$ denote significance at the $10 \%, 5 \%$, and $1 \%$ levels, respectively.

sents the corresponding effects on government health expenditure. We see that the coefficient of the pandemic variable $(P)$ is 1.207 , but statistically insignificant, implying 
Table 3: Robustness test results

\begin{tabular}{|c|c|c|c|c|}
\hline \multirow[t]{2}{*}{ Variable } & \multicolumn{2}{|c|}{$\begin{array}{c}\text { Model } 1 \\
\text { (dependent variable: government expenditure) }\end{array}$} & \multicolumn{2}{|c|}{$\begin{array}{c}\text { Model } 2 \\
\text { (dependent variable: government health } \\
\text { expenditure) }\end{array}$} \\
\hline & $\begin{array}{l}\text { Developing } \\
\text { countries }\end{array}$ & $\begin{array}{l}\text { Developed countries/ } \\
\text { regions }\end{array}$ & $\begin{array}{l}\text { Developing } \\
\text { countries }\end{array}$ & $\begin{array}{l}\text { Developed countries/ } \\
\text { regions }\end{array}$ \\
\hline Pandemic & $\begin{array}{c}1.847 \\
(1.761)\end{array}$ & $\begin{array}{c}0.009 \\
(0.001)\end{array}$ & $\begin{array}{l}0.311^{* *} \\
(0.092)\end{array}$ & $\begin{array}{l}-0.348 \\
(0.238)\end{array}$ \\
\hline Population growth & $\begin{array}{l}-0.168 \\
(0.085)\end{array}$ & $\begin{array}{l}-0.013^{* *} \\
(0.002)\end{array}$ & $\begin{array}{c}0.211 \\
(0.164)\end{array}$ & $\begin{array}{c}0.068 \\
(0.116)\end{array}$ \\
\hline Life expectancy & $\begin{array}{l}1.583 \\
(3.945)\end{array}$ & $\begin{array}{l}3.306^{* * *} \\
(0.326)\end{array}$ & $\begin{array}{l}2.351 \\
(2.691)\end{array}$ & $\begin{array}{l}116.352^{* *} \\
(26.199)\end{array}$ \\
\hline GDP per capita & $\begin{array}{l}-0.079 \\
(0.447)\end{array}$ & $\begin{array}{c}1.490 \\
(0.546)\end{array}$ & $\begin{array}{c}0.757 \\
(0.457)\end{array}$ & $\begin{array}{c}-10.938 \\
(4.694)\end{array}$ \\
\hline Government revenue & $\begin{array}{c}0.027 \\
(0.026)\end{array}$ & $\begin{array}{c}0.005 \\
(0.178)\end{array}$ & $\begin{array}{c}0.024 \\
(0.027)\end{array}$ & $\begin{array}{l}-4.111 \\
(2.853)\end{array}$ \\
\hline $\begin{array}{l}\text { National income per } \\
\text { capita }\end{array}$ & $\begin{array}{l}0.888^{* * *} \\
(0.141)\end{array}$ & $\begin{array}{l}-0.792 \\
(0.376)\end{array}$ & $\begin{array}{c}0.252 \\
(0.280)\end{array}$ & $\begin{array}{c}4.482 \\
(4.295)\end{array}$ \\
\hline Constant & $\begin{array}{c}6.456 \\
(14.144)\end{array}$ & $\begin{array}{l}4.026 \\
(2.231)\end{array}$ & $\begin{array}{l}-15.291 \\
(10.545)\end{array}$ & $\begin{array}{c}-323.242^{*} \\
(92.828)\end{array}$ \\
\hline Observation & 114 & 57 & 114 & 57 \\
\hline $\mathrm{R}^{2}$ & 0.088 & 0.943 & 0.156 & 0.105 \\
\hline
\end{tabular}

Notes: This table reports the sub-sample results of the panel fixed effect model. The values in parentheses denote the standard errors. Finally, ${ }^{*}, * * ;$, and ${ }^{* * * *}$ denote significance at the $10 \%, 5 \%$, and $1 \%$ levels, respectively.

that the outbreak of pandemics increases government expenditure. The reason might be that pandemics have a negative impact on public revenues and thus put government finances under pressure (Kum et al., 2019; Makananisa, 2020). Governments will thus transfer budget expenditures from other projects to pandemic management when implementing pandemic interventions, and so the increase in total government expenditure is insignificant. We see that the control variable, $N I$, has a significant negative effect on government expenditure.

The estimation results of government health expenditure nonetheless exhibit some differences, as shown in Model 2. The coefficient $P$ is 0.347 at the $1 \%$ significance level, which means that a government will increase public health expenditure when a pandemic spreads. The control variable $P G$ has a positive effect on government health expenditure at the $10 \%$ significance level.

Table 3 presents the results of the robustness test. As we can see, the effect of the pandemic in developing countries is consistent with the full sample results.

\section{Conclusion}

Based on a sample of panel data for 14 countries spanning the period 2000-2018, this paper investigates the effects of pandemics on government expenditure and public health expenditure. The empirical results show that pandemics lead to an increase in government health expenditure, but the positive effect on total government expenditure may not be statistically significant.

The COVID-19 pandemic is more severe and widespread than previous pandemics/epidemics like SARS, H1N1, or EVD. In terms of the number of confirmed cases and deaths, COVID-19 represents a huge loss of labor force and human capital. Consumption and foreign trade have also been seriously damaged by restrictions on the movement of people and strict controls/quarantine of imported goods at ports, which would put downward pressure on government revenues.

Submitted: November 24, 2020 AEDT, Accepted: February 09, 2021 AEDT 


\section{REFERENCES}

Alfano, V., \& Ercolano, S. (2020). The efficacy of lockdown against COVID-19: A cross-country panel analysis. Applied Health Economics and Health Policy, 18(4), 509-517. https://doi.org/10.1007/s40258-020-0 0596-3

Awaworyi, S., Yew, S. L., \& Ugur, M. (2015). Effects of government education and health expenditures on economic growth: A meta-analysis. SSRN Electronic Journal, 420. https://doi.org/10.2139/ssrn.2693942

Birchenall, J. A. (2007). Escaping high mortality. Journal of Economic Growth, 12(4), 351-387. https://do i.org/10.1007/s10887-007-9022-2

Goel, R. K., Payne, J. E., \& Ram, R. (2008). R\&D expenditures and U.S. economic growth: A disaggregated approach. Journal of Policy Modeling, 30(2), 237-250. https://doi.org/10.1016/i.jpolmod.200 $\underline{7.04 .008}$

Guo, P., Liu, L. F., \& Xiao, H. X. (2011). Contribution analysis of government health expenditure to economic growth under endogenous growth model. Statistics \& Decision, 7, 94-97. https://doi.org/CNKI:S UN:TJJC.0.2011-07-029

Haldar, A., \& Sethi, N. (2020). The Effect of Countrylevel Factors and Government Intervention on the Incidence of COVID-19. Asian Economics Letters, 1(2). https://doi.org/10.46557/001c.17804

He, P., Sun, Y., Zhang, Y., \& Li, T. (2020). COVID-19's impact on stock prices across different sectors - An event study based on the Chinese stock market. Emerging Markets Finance and Trade, 56(10), 2198-2212. https://doi.org/10.1080/1540496x.2020.1 785866

Iyke, B. N. (2020). The disease outbreak channel of exchange rate return predictability: Evidence from COVID-19. Emerging Markets Finance and Trade, 56(10), 2277-2297. https://doi.org/10.1080/1540496 $\underline{\mathrm{x} .2020 .1784718}$

Kum, F. V., Olayiwola, S., \& Aloysius, N. M. (2019). The Impact of Ebola Virus Disease on Government Expenditure in Sierra Leone. In G. B. Tangwa, A. Abayomi, S. J. Ujewe, \& N. S. Munung (Eds.), Sociocultural Dimensions of Emerging Infectious Diseases in Africa (pp. 75-90). Springer Nature Switzerland AG.

Lee, J.-W., \& Mckibbin, W. J. (2004). Globalization and disease: The case of SARS. Asian Economic Papers, 3(1), 113-131. https://doi.org/10.1162/153535 1041747932
Makananisa, M. P. (2020). The impact of COVID-19 and lockdown on South African revenue. Journal of Economics \& Management Research, 1(3), 1-7. http s://doi.org/10.47363/jesmr/2020(1)109

Maliszewska, M. (2014). The economic impact of the 2014 Ebola epidemic: Short and medium term estimates for West Africa. World Bank Publications.

Ming, W., Zhou, Z., Ai, H., Bi, H., \& Zhong, Y. (2020). COVID-19 and air quality: Evidence from China. Emerging Markets Finance and Trade, 56(10), 2422-2442. https://doi.org/10.1080/1540496x.2020.1 790353

Mishra, A. K., Rath, B. N., \& Dash, A. K. (2020). Does the Indian financial market nosedive because of the COVID-19 outbreak, in comparison to after demonetization and the GST? Emerging Markets Finance and Trade, 56(10), 2162-2180. https://doi.or $\mathrm{g} / 10.1080 / 1540496 X .2020 .1785425$

Narayan, P. K. (2020a). Did bubble activity intensify during COVID-19? Asian Economics Letters. In press.

Narayan, P. K. (2020b). Oil price news and COVID-19-Is there any connection? Energy Research Letters, 1(1), 13176. https://doi.org/10.46557/001c.13 $\underline{176}$

Narayan, P. K. (2020c). Has COVID-19 Changed Exchange Rate Resistance to Shocks? Asian Economics Letters, 1(1). https://doi.org/10.46557/001c.17389

Narayan, P. K., \& Smyth, R. (2005). Trade liberalization and economic growth in Fiji. An empirical assessment using the ARDL approach. Journal of the Asia Pacific Economy, 10(1), 96-115. http s://doi.org/10.1080/1354786042000309099

Phan, D. H. B., \& Narayan, P. K. (2020). Country responses and the reaction of the stock market to COVID-19-a Preliminary Exposition. Emerging Markets Finance and Trade, 56(10), 2138-2150. http s://doi.org/10.1080/1540496x.2020.1784719

Salisu, A. A., \& Adediran, I. (2020). Uncertainty due to infectious diseases and energy market volatility. Energy Research Letters, 1(2), 14185. https://doi.org/1 $\underline{0.46557 / 001 \mathrm{c} .14185}$

Salisu, A. A., \& Sikiru, A. A. (2020). Pandemics and the Asia-Pacific Islamic Stocks. Asian Economics Letters, 1(1). https://doi.org/10.46557/001c.17413 
Sha, Y., \& Sharma, S. S. (2020). Research on Pandemics Special Issue of the Journal. Emerging Markets Finance and Trade, 56(10), 2133-2137. http s://doi.org/10.1080/1540496x.2020.1795467

Sharma, S. S., \& Sha, Y. (2020). Part A: Special Section on COVID-19 Research. Emerging Markets Finance and Trade, 56(15), 3551-3553. https://doi.or $\mathrm{g} / 10.1080 / 1540496 x .2020 .1858617$
Vidya, C. T., \& Prabheesh, K. P. (2020). Implications of COVID-19 pandemic on the global trade networks. Emerging Markets Finance and Trade, 56(10), 2408-2421. https://doi.org/10.1080/1540496x.2020.1 $\underline{785426}$

Yu, Z., Xiao, Y., \& Li, Y. (2020). The response of the labor force participation rate to an epidemic: Evidence from a cross-country analysis. Emerging Markets Finance and Trade, 56(10), 2390-2407. http s://doi.org/10.1080/1540496x.2020.1784717 